\title{
Antioxidant activity and physical-chemical properties of spray and spouted bed dried extracts of Bauhinia forficata
}

\author{
Claudia Regina Fernandes Souza ${ }^{*}$, Sandra Regina Georgetti², Marcos José Salvador ${ }^{3}$, Maria José \\ Vieira Fonseca $^{1}$, Wanderley Pereira Oliveira ${ }^{1}$
}

\begin{abstract}
${ }^{I}$ Department of Pharmaceutical Sciences, Faculty of Pharmaceutical Sciences of Ribeirão Preto, University of São Paulo, ${ }^{2}$ Department of Food and Drugs Technology, Healthy Sciences Center, State University of Londrina, ${ }^{3}$ Institute of Biology, State University of Campinas
\end{abstract}

\begin{abstract}
Two distinct drying methods (spouted bed and spray drying) were used for production of dried extracts of Bauhinia forficata Link (Leguminosae, Caesalpinoideae). High-quality powder products in terms of physical and chemical properties were obtained. HPLC fingerprints revealed that the chromatographic profiles of flavonoid compounds present in the dried extract did not change significantly, due to drying. In general, the spouted bed drying caused a degradation of total flavonoids than was lower than that of the spray drying. Antioxidant properties of the dried extract, examined by their radical scavenging activity using 2,2-diphenyl-1-picrylhydrazyl radical (DPPH*) and inhibition of lipid peroxidation induced by $\mathrm{Fe}^{+2}$ assays (LPO), confirmed their antioxidant potential. The slight reduction in scavenging activity of the dried extracts may be associated with the occurrence of oxidative reactions, decomposition or losses of thermolabile compounds, induced by the heat.
\end{abstract}

Uniterms: Bauhinia forficata/antioxidant activity. Bauhinia forficata/dried extract/properties. Flavonoids/ qualitative analysis. Spouted bed/utilization. Spray drying/utilization.

\begin{abstract}
Neste trabalho foram utilizados dois distintos secadores (leito de jorro e spray dryer) para a produção de extratos secos de Bauhinia forficata Link (Leguminosae, Caesalpinoideae) obtendo-se um produto seco com elevada qualidade em termos de suas propriedades físicas e químicas. Análises qualitativas obtidas por CLAE revelam que os perfis cromatográficos dos compostos flavonóides presentes nos extratos secos não apresentaram significativas mudanças durante a secagem quando comparados aos perfis obtidos para os extratos concentrados. Em geral, a secagem por leito de jorro acarreta menores perdas dos flavonóides totais do que a secagem em spray drying. A atividade antioxidante dos extratos secos foi examinada pelos métodos de $\left(\mathrm{DPPH}^{\bullet}\right)$ e peroxidação lipídica induzida por $\mathrm{Fe}^{+2}$ (LPO). Uma pequena redução na atividade sequestradora de radicais livres observada para os extratos secos pode ser associada com a ocorrência de reações oxidativas, decomposição e/ou perdas de compostos termolábeis induzidas pelo calor.
\end{abstract}

Unitermos: Bauhinia forficata/atividade antioxidante. Bauhinia forficata/extrato seco/propriedades. Flavonóides/análise qualitativa. Leito de jorro/utilização. Spray drying/utilização.

\section{INTRODUCTION}

Currently, the causes of several diseases such as liver cirrhosis, arteriosclerosis, cancer, and diabetes have been associated with the presence of free radicals. These radicals may cause oxidative damage by oxidizing bio-

\footnotetext{
*Correspondence: C. R. F. Souza. Departamento de Ciências Farmacêuticas, Faculdade de Ciências Farmacêuticas de Ribeirão Preto, University of São Paulo. Via do Café, s/n - Bloco Q - Bairro Monte Alegre - 14040-903 - Ribeirão Preto - SP. E-mail: souzacrf@gmail.com
}

molecules, and it results in cellular death and consequent tissue damage. Therefore, free radicals scavenging compounds may have a great potential to inhibit or reduce the oxidative damage on the human body (Brighente et al., 2007; Moein et al., 2007; Sabu, Kuttan, 2002).

On the other hand, diabetes disease is increasing rapidly and consuming vast amounts of health care resources worldwide (Sousa et al., 2004). In Latin America, the prevalence of type 2 diabetes mellitus among the younger age groups (20 to 44 years) has shown an upward trend, 
having negative impact on quality of life and burdening the health care system (Sartorelli, Franco, 2003).

In the Brazilian folk medicine, Bauhinia forficata Link (Leguminosae, Caesalpinoideae), commonly known as pata-de-vaca (paw-of-cow), has been widely used as an antidiabetic herbal remedy (Pepato et al., 2002; Pepato et al., 2004; Silva, Cechinel, 2002). This plant species is characterized by the accumulation of flavonoids (glycosides and aglycones) in their leaves (Jorge et al., 2004). Phytochemical and pharmacological studies carried out with Bauhinia species have demonstrated the presence of several classes of organic compounds of medicinal interest, including the flavonoids (Silva, Cechinel, 2002). Antioxidant properties (Sousa et al., 2004; Damasceno et al., 2004), anticoagulant and antifibrinogenolytic activities against Bothrops jararacussu Lacerda, 1884 (Ophidia, Viperidae) venom and its isolated thrombin-like serine protease enzyme, induced by aqueous extract from this plant, have been also reported (Oliveira et al., 2005). Several chemical constituents, including lactones, terpenoids, glycosyl steroids, alkaloids, flavonoids, mucilage, essential oils, tannins and quinines have been isolated and identified from this species. Several authors have investigated the effects of natural flavonoids in physiological and pathological conditions of glucose metabolism as well as in lipid peroxidation (Silva et al., 2000; Sousa et al., 2004; Damasceno et al., 2004; Menezes et al., 2007; Volpato et al., 2008). Souza et al. (2004) verified that the kaempferitrin, a flavonoid fraction from Bauhinia forficata leaves, posses strong antioxidant potential. Pinheiro et al. (2006) have made attempts in order to correlate the attributed antidiabetic properties of the Bauhinia forficata extract to the kaempferitrin.

The quality of medicinal plants can be affected by many factors, including species variation, climate, harvesting, storage, and processing. Consequently, the standardization and quality control of herbs are important issues to assure the efficacy and safety of herbal medicines (Pietta, Mauri, 2001). Commonly, standardized herbal preparations are commercialized as liquid, viscous preparations and powders resulting from dried and comminuted plants, or from an extract drying. Important advantages attributed to the dried extracts over conventional forms are the facility of standardization, lower storage costs and higher concentration and stability of active substances. However, the drying method and the operating conditions used for the production of the dried extract may impact the product physicochemical properties, and can originate varying degrees of active compounds loss (Runha et al., 2001; Souza, Oliveira, 2006; Oliveira, Bott, Souza, 2006).

The aim of this work was the evaluation of the effects of the spouted bed and spray drying on antioxidant activity and physical-chemical properties of dried extracts of Bauhinia forficata Link.

\section{MATERIALS AND METHODS}

\section{Plant material, chemicals and extract preparation}

Dried leaves of Bauhinia forficata were acquired from Santa Rosa's Farm, located in Jundiaí city, São Paulo State, Brazil. The leaves were pulverized in a knife mill until a mean diameter of $300 \mu \mathrm{m}$. This material was characterized by determination of loss on drying, extractable matter and total flavonoid content, used as a chemical marker for quantification of the bioactive compounds degradation during drying. The procedures used in this characterization are presented in Souza and Oliveira (2006).

Ethyl acetate, methanol, acetone, aluminum chloride, ethanol, hydrochloric acid (LabSynth), hexamethylenetetramine (Vetec), colloidal silicon dioxide (Tixosil $333^{\circledR}$, Rhodia - Brazil), dehydrated quercetin (Sigma-A1drich) and 2,2-diphenyl-1-picrylhydrazyl (DPPH', SigmaAldrich) were used as reagents and reference substances.

Dried and powdered leaves were placed in contact with an ethanol:water solution (70:30 in weight) at temperature of $50{ }^{\circ} \mathrm{C}$ in a jacketed stirred vessel. The extraction time lasted $60 \mathrm{~min}$ at stirring rate of $200 \mathrm{rpm}$. The extract was filtered and concentrated three times in a rotary evaporator (vacuum pressure of $600 \mathrm{mmHg}$ and $50{ }^{\circ} \mathrm{C}$ ), and its density, solid concentration, alcohol, and total flavonoid content was determined.

\section{Determination of total flavonoid contents}

Total flavonoid contents present in the herbal material, concentrated and dried extracts was used as bioactive marker for the evaluation of thermal degradation during the processing stages. The total flavonoid contents was determined by UV spectrophotometry. The method includes the hydrolysis of glycosides, followed by the extraction of flavonoids with ethyl acetate and color development with a solution of aluminum chloride (Kulevanova, Stefova, Stafilov, 2000; Souza, 2003). Absorbance was measured at $425 \mathrm{~nm}$ after $30 \mathrm{~min}$, using a spectrophotometer HP 8453 running the software HP Chem-Station ${ }^{\circledR}$. The percentage of total flavonoid $\left(\mathrm{F}_{\mathrm{T}}\right)$ was expressed as quercetin (average of three determinations), by means of a calibration curve.

\section{HPLC-DAD fingerprints}

Samples of $100 \mathrm{mg}$ (dry-basis) of the extracts were dissolved in $4 \mathrm{~mL}$ of methanol:water $(1: 1, \mathrm{v} / \mathrm{v})$, sonicated 
for $15 \mathrm{~min}$ in an ultrasonic bath (Odontobras, model 802) and put to rest for $24 \mathrm{~h}$. After this period, the samples were filtered through $0.45 \mu \mathrm{m}$ polytetrafluoroethylene syringe tip filters into the glass HPLC vials. The analyses were carried out in a Shimadzu liquid chromatograph equipped with a Supelco RP-18 column ( 225 x 4.6 mm i.d.; $5 \mu \mathrm{m})$ operating at $25^{\circ} \mathrm{C}$. The mobile phase consisted of a linear gradient combining solvent $\mathrm{A}$ (acetonitrile) and solvent $\mathrm{B}$ (water/acetic acid, 99:1, v/v, $\mathrm{pH} 2.88$ ) as follows: 15\% A (15 min), 15-20\% A (7 min), 20\% A (5 min), 20-40\% A ( $5 \mathrm{~min}), 40 \% \mathrm{~A}(5 \mathrm{~min}), 40-15 \% \mathrm{~A}(3 \mathrm{~min})$. The analyses were carried out in triplicate, at a flow rate of $0.8 \mathrm{~mL} / \mathrm{min}$, with the photodiode array UV detector set at $\lambda=330 \mathrm{~nm}$ and an injection volume of $20 \mu \mathrm{L}$. The flavanone naringe$\operatorname{nin}(25 \mu \mathrm{g} / \mathrm{mL})$ was used as internal standard.

\section{Extracts drying}

Two distinct drying systems (spouted bed and spray dryer) were used for production of the dried extracts. The spouted bed dryer consists of a conical base with internal angle of $40^{\circ}$ and inlet orifice diameter of $33 \mathrm{~mm}$. A cylindrical column with diameter of $150 \mathrm{~mm}$ and height of $400 \mathrm{~mm}$ is connected to the conical base of the dryer. The upper part of the equipment is constituted by another cone and by a cyclone. All parts are made in stainless steel. Teflon ${ }^{\circledR}$ beads of concave-cylindrical shape with mean diameter of $5.45 \mathrm{~mm}$, shape factor of 0.96 , specific surface of $5.27 \mathrm{~cm}^{2} / \mathrm{g}$ and density of $2.16 \mathrm{~g} / \mathrm{cm}^{3}$ were used as inert material. Teflon was selected due to its inert nature, high thermal stability, low coefficient of friction, insolubility and lack of toxicological effects (Tzeng et al., 1997). The main components of the system are a 7.5 HP blower, a flow meter, an electric heater (power of $5000 \mathrm{~W}$ ), and a temperature controller. The extract feed system consists of a double fluid atomizer with internal mixing $(0.8 \mathrm{~mm}$ hole), a peristaltic pump and an air compressor. The dried product was collected in a stainless steel Lapple type cyclone with diameter of $0.095 \mathrm{~m}$, having a cut diameter of $4.1 \mu \mathrm{m}$ (for the experimental conditions used). Thermocouples, pressure transducers and a thermo-hygrometer were employed in the equipment instrumentation.
Spray drying was carried out in a bench-top spray dryer, model SD-05 (Lab-Plant, U.K.), with concurrent flow regime. The drying chamber has diameter of $215 \mathrm{~mm}$ and height of $500 \mathrm{~mm}$. The main components of the system were the extract feed unit, constituted of a peristaltic pump, a two fluid atomizer (inlet orifice diameter of $0.5 \mathrm{~mm}$ ) and an air compressor; a feed mechanism of the drying gas (constituted of a blower and an air filter), and a temperature control unit of the drying gas. The dried product was collected in a Lapple cyclone with diameter of $0.085 \mathrm{~m}$ (cut diameter of $3.9 \mu \mathrm{m}$ ).

The drying runs were performed at optimized operating conditions obtained from previous studies (Souza, 2003). The drying operation started with injection of the drying air to the dryers. The air was heated and, when reached the desired temperature, the feed of the concentrated extracts with a preset flow rate together with the atomizing air was started. Measurements of the outlet gas temperature, $\mathrm{T}_{\mathrm{go}}$, were taken at regular intervals in order to detect the moment when the dryers attained the steady state ( $\pm 15 \mathrm{~min}$ ). Once the steady state was reached, samples of the dried extract were withdrawn. The samples were used for the assessment of the antioxidant activity and characterization of the physical and chemical properties. The size distribution was determined by an optical microscope Olympus BX60MI connected to an image analysis system (Image Pro-plus 4.5). Colloidal silicon dioxide (Tixosil ${ }^{\circledR}$ 333 - Rhodia, Brazil) was added to the concentrated extracts before drying, to improve the dryer performance ( $80 \%$ calculated on the solid contents). Table I shows the operational parameters used in the drying runs.

\section{Assessment of the antioxidant activity of concentrated and dried extracts}

$\mathrm{DPPH}^{\bullet}$ is a stable free radical that reacts with compounds, which are able to donate a hydrogen atom (Blois, 1958; Brand-Willians et al., 1995). The hydrogen donating ability of the concentrated and dried extracts of $B$. forficata to $\mathrm{DPPH}^{\bullet}$ was determined according to Blois (1958). The concentrated extract $(10 \mu \mathrm{L})$ at different dilutions $(1: 10$, $1: 20,1: 50,1: 100$, and $1: 200)$ and of the dried extract of $B$.

TABLE I - Spouted bed and spray drying parameters used in manufacture of the dried extract

\begin{tabular}{lcccc}
\hline Dryer & $\mathrm{T}_{\mathrm{gi}}\left({ }^{\circ} \mathrm{C}\right)$ & $\mathrm{W}_{\mathrm{s}} / \mathrm{W}_{\max }(\%)$ & $\mathrm{W}_{\mathrm{s}}(\mathrm{g} / \mathrm{min})$ & $\mathrm{W}_{\mathrm{g}}(\mathrm{kg} / \mathrm{s})$ \\
\hline SB & 150 & 45 & 33.0 & 0.0340 \\
SD & 150 & 15 & 4.0 & 0.0227 \\
\hline
\end{tabular}

SB: spouted bed dryer; $\mathrm{SD}$ : spray dryer; $\mathrm{T}_{\mathrm{gi}}$ : inlet gas temperature; $\mathrm{W}_{\mathrm{s}} / \mathrm{W}_{\max }$ : feed extract mass flow rate relative to evaporation capacity of the dryer; $\mathrm{W}_{\mathrm{s}}$ : feed extract flow rate; $\mathrm{W}_{\mathrm{g}}$ : feed gas flow rate 
forficata $(6.25-0.375 \mu \mathrm{g} / \mathrm{mL})$ in ethanol were added in a reaction mixture containing $1 \mathrm{~mL}$ of $0.1 \mathrm{M}$ acetate buffer $\mathrm{pH} 5.5,1 \mathrm{~mL}$ of ethanol, and $0.5 \mathrm{~mL}$ of $250 \mu \mathrm{M} \mathrm{DPPH}^{\bullet}$ $\mu \mathrm{M}$ in ethanol solution. The resulting samples concentrations in the reaction medium were $0.02-0.4 \mu \mathrm{L} / \mathrm{mL}$ and $1.5-25 \mu \mathrm{g} / \mathrm{mL}$, respectively. The change in absorbance was measured at $517 \mathrm{~nm}$ after $15 \mathrm{~min}$ (at room temperature). All measurements were made in quintuplicate (Fejes et al., 2002; Nuutila, Kammiovirta, Oksman-Caldentey, 2006; Georgetti et al., 2006; Casagrande et al., 2007).

Lipid peroxidation induced by $\mathrm{Fe}^{+2} /$ citrate (LPO) was assayed by malondialdehyde (MDA) generation (Rodrigues et al., 2002; Cain, Skilleter, 1987) in the presence of different concentrations of $B$. forficata extracts. Mitochondria were prepared by standard differential centrifugation techniques as described by Rodrigues et al. (2002) and by Cain and Skilleter (1987). $10 \mu \mathrm{L}$ of the concentrated extract $(1: 10-1: 200)$ and dried extract $(0.15-2.5 \mathrm{mg} / \mathrm{mL})$ a $\mathrm{t}$ different concentrations $(12.5-300 \mu \mathrm{g} / \mathrm{mL}$ in DMSO) were added to $1.0 \mathrm{~mL}$ of a reaction mixture $(125 \mathrm{mmol} / \mathrm{L}$ sucrose, $65 \mathrm{mmol} / \mathrm{L} \mathrm{KCl}$ and $10 \mathrm{mmol} / \mathrm{L}$ Tris- $\mathrm{HCl}$, pH 7.4 - medium I). Mitochondria were added to yield a final concentration of $1 \mathrm{mg}$ of protein plus $50 \mu \mathrm{M}\left(\mathrm{NH}_{4}\right)_{2} \mathrm{Fe}(\mathrm{SO})_{4}$ and $2 \mathrm{mM}$ sodium citrate for $30 \mathrm{~min}$ at $37^{\circ} \mathrm{C}$. The final concentrations of the concentrated and dried extracts in the reaction medium were $0.02-0.4 \mu \mathrm{L} / \mathrm{mL}$ and $0.6-10 \mu \mathrm{g} / \mathrm{mL}$, respectively. To determine MDA, $1 \mathrm{~mL}$ of $1 \%$ thiobarbituric acid (TBA), prepared in $50 \mathrm{mM} \mathrm{NaOH}$, and $0.1 \mathrm{~mL}$ of $10 \mathrm{M} \mathrm{NaOH}$ and $0.5 \mathrm{~mL}$ of $20 \% \mathrm{H}_{3} \mathrm{PO}_{4}$ were added, followed by incubation for $20 \mathrm{~min}$ at $85^{\circ} \mathrm{C}$. The MDATBA complex was extracted with $2 \mathrm{~mL}$ of isobutanol. The samples were then centrifuged at $1660 \mathrm{~g}$ for $10 \mathrm{~min}$. The measurement was performed on the supernatant at $535 \mathrm{~nm}$ (Casagrande et al., 2007; Rodrigues et al., 2002; Santos et al., 1998). Two controls were used, a positive control (samples absence) and a negative control (iron absence). The blank was prepared from the medium I without mitochondria. Thus, the positive control indicates the maximum MDA formation, which was considered $100 \%$ of peroxidation to calculate the inhibition of lipid peroxidation by the antioxidants retained in the dried extracts. All measurements were performed in quintuplicate. Quercetin was used as a reference sample for both assays.

\section{Statistical analysis}

The concentration of dried extract that caused 50\% of the hydrogen-donating ability and/or lipid peroxidation was considered as the $\mathrm{IC}_{50}$ in each assay. These values were determinate through the GraphPad Prism ${ }^{\circledR}$ software. Experimental $\mathrm{IC}_{50}$ results were statistically analyzed by one-way ANOVA, followed by Bonferroni's multiple comparisons $t$-test to evaluate the effect of the drying process on antioxidant activity. Results were expressed as mean \pm standard deviation and considered significant when $P<0.05$.

\section{RESULTS AND DISCUSSION}

\section{Characterization of the herbal material and extractive solution}

The herbal material presented moisture content (loss on drying) of $9.5 \pm 0.2(\% \mathrm{w} / \mathrm{w})$, extractable matter (ethanol:water mixture) of $26.7 \pm 0.05(\% \mathrm{w} / \mathrm{w})$ and total flavonoid content of $1.36 \pm 0.2(\% \mathrm{w} / \mathrm{w})$. The extractive solution was prepared by placing the pulverized herbal material in contact with ethanol:water solution (70:30 in weight) at temperature of $50{ }^{\circ} \mathrm{C}$ in a jacketed stirred vessel with controlled temperature. The extractive solution was concentrated three times in order to increase the solids content to approximately $8.0 \%$. The properties of the extractive solution and of the concentrated extract are presented at Table II. The results of total flavonoid contents $\left(\mathrm{F}_{\mathrm{T}}\right)$ in the concentrated extract (EC) showed a thermal degradation rate of the order of $5.89 \%$, as compared to the results of the extractive solution. Ethanol is more volatile and has a lower boiling point than water, presenting a greater tendency to be removed from the extractive solution during concentration, than water does. This fact leads to a concentrated extract with reduced alcohol concentration.

\section{Drying performance and product properties}

Spouted bed and spray drying performances were evaluated through determination of the elutriation ratio, $\mathrm{E}$; product recovery ratio, $\mathrm{R}$; and, product accumulation

TABLE II - Properties of the extractive solution and of the concentrated extract

\begin{tabular}{lcccc}
\hline Extracts & $\mathrm{F}_{\mathrm{T}}\left(\% \mathrm{mg} / \mathrm{g}_{\text {extract }}\right)$ & $\rho\left(\mathrm{g} / \mathrm{cm}^{3}\right)$ & Solid contents $(\% \mathrm{w} / \mathrm{w})$ & Alcohol content $\left({ }^{\circ} \mathrm{GL}\right)$ \\
\hline ES & $13.92 \pm 0.05$ & $0.96 \pm 0.009$ & $2.66 \pm 0.02$ & 70.0 \\
EC & $13.10 \pm 0.03$ & $0.95 \pm 0.010$ & $8.05 \pm 0.06$ & 0.0 \\
\hline
\end{tabular}

$\mathrm{F}_{\mathrm{T}}$ : Chemical markers (flavonoids); ES: extractive solution; EC: concentrated extract; $\rho$ : density 
TABLE III - Spray and spouted bed dryers performance and properties of the dried extracts

\begin{tabular}{lccccccccc}
\hline Dryer & \multicolumn{3}{c}{ Dryer performance } & \multicolumn{4}{c}{ Dried extract properties } \\
\hline & $\begin{array}{c}\mathrm{R}^{* *} \\
(\%)\end{array}$ & $\begin{array}{c}\mathrm{E} \\
(\%)\end{array}$ & $\begin{array}{c}\mathrm{Ac}^{*} \\
(\%)\end{array}$ & $\begin{array}{c}\mathrm{W}_{\mathrm{s}} \\
(\mathrm{g} / \mathrm{min})\end{array}$ & $\begin{array}{c}\mathrm{T}_{\mathrm{go}} \\
\left({ }^{\circ} \mathrm{C}\right)\end{array}$ & $\begin{array}{c}\mathrm{F}_{\mathrm{T}}^{* *} \\
\left(\% \mathrm{mg} / \mathrm{g}_{\text {extract }}\right)\end{array}$ & $\begin{array}{c}\mathrm{D} \\
(\%)\end{array}$ & $\begin{array}{c}\mathrm{X}_{\mathrm{p}} \\
(\%)\end{array}$ & $\begin{array}{c}\mathrm{d}_{\mathrm{p}} \\
(\mu \mathrm{m})\end{array}$ \\
\hline SB & 78.44 & 19.36 & 2.20 & 33.18 & 116.2 & $13.08 \pm 0.01$ & 0.2 & $3.99 \pm 0.22$ & 21.8 \\
$\mathrm{SD}$ & 48.90 & 51.10 & - & 2.90 & 108.0 & $7.87 \pm 0.05$ & 39.9 & $3.78 \pm 1,21$ & 14.4 \\
\hline
\end{tabular}

"Ac: accumulation rate (only for SB); R: product recovery; E: elutriation; $\mathrm{F}_{\mathrm{T}}$ : total flavonoid contents; $\mathrm{D}$ : thermal degradation of flavonoid compounds; $\mathrm{X}_{\mathrm{p}}$ : loss on drying; $\mathrm{d}_{\mathrm{p}}$ : mean particle diameter; $\mathrm{T}_{\mathrm{go}}$ : outlet gas temperature.

** Statistically significant difference $(P<0.05)$.

(only for the spouted bed), Ac (Souza, Oliveira, 2006; 2005). The dried extracts were characterized by the loss on drying, total flavonoids concentration and HPLC-DAD fingerprint, product size distribution, antioxidant activity, and physical properties. Table III presents the spray and spouted bed dryers' performance and the properties of the dried extracts. It can be observed at Table III that the spouted bed dryer gives an end product with higher concentration of chemical markers and small loss on drying values $(\approx$ low residual moisture content) than the spray dryer does. The spouted bed dryer also presented a better performance than the spray dryer, leading to higher product recovery. The spouted bed drying gives an end product with higher concentration of the chemical markers and lower loss on drying values than the spray drying; even both processes working at similar relation $\mathrm{W}_{\mathrm{s}} / \mathrm{W}_{\max }$ and inlet gas temperatures. Similar results have been reported elsewhere (Oliveira, Bott, Souza, 2006).

The particle size distribution is an important property, which may be related with bioavailability and uniform and constant release of the product (Freitag, 2001). Polydisperse particles within a limited range (0 to $30 \mu \mathrm{m})$ were obtained by both drying systems. Spouted bed drying generates irregular particles with flakes shape, whereas the spray drying process gives a high proportion of near rounded particles.

In general, during hot air drying the product is exposed to high temperatures and high oxygen levels. In addition, the solids concentration increases during drying (removal of solvent). These factors may increase the rate of oxidative and degradation reactions, reducing the product quality (Giovanelli, Paradiso, 2002). Degradation rates of $0.2 \%$ were observed for the spouted bed dried, smaller than the observed for the spray dried product $(39.9 \%)$. This behavior possibly is related with the distinct drying mechanism involved in both dryers and may be related with the different residence time of the product in the dryers. In order to verify the occurrence of alteration in the flavonoid compounds chromatographic profiles presented in the concentrated and in the dried extract, HPLC-DAD analyses were carried out. The chromatographic profiles were used only to find out changes in the relative magnitudes of the peaks, in order to know if major changes have occurred. Figure 1 shows typical chromatograms obtained for the concentrated extracts (reference sample) and for the spouted bed and spray dried extracts. HPLC-DAD analyses performed for the $B$. forficata extracts did not indicate significant alteration in the chromatographic profiles of the dried product, comparatively with the concentrated extracts. However, although the same peaks were presented in the HPLC chromatograms, the peaks magnitude may differ, suggesting molecular changes due to the drying (oxidation, enzymatic hydrolyses, etc).

\section{Antioxidant activity of concentrated and dried extracts}

The antioxidant properties of the concentrated (used as a control) and resulting dried extracts were assessed by the $\mathrm{DPPH}^{\bullet}$ and LPO methods. The parameter $\mathrm{IC}_{50}$ (concentration needed to inhibit the oxidative reaction by $50 \%$ ) was used to interpret the experimental data. Quercetin, a natural antioxidant, was used here as a standard reference material. This flavonoid presented a concentrationdependent hydrogen-donating ability and showed an $\mathrm{IC}_{50}$ of $1.17 \mu \mathrm{g} / \mathrm{mL}$. The maximum percentage of hydrogendonating ability (89.0\%) was obtained using $4 \mu \mathrm{g} / \mathrm{mL}$; at a higher concentration $(10 \mu \mathrm{g} / \mathrm{mL})$ a plateau effect was observed (Casagrande et al., 2007). Table IV shows, respectively, the results of the $\mathrm{DPPH}{ }^{\bullet}$ inhibition produced by the concentrated extract (EC), for the spouted bed (SB) and for the spray dried extract (SD). The results indicate that the free radical scavenging activity of the analyzed samples were concentration dependent. The maximum $\mathrm{DPPH}^{*}$ reduction promoted by the concentrated extract was approximately $76 \%$ at a concentration of $39.2 \mu \mathrm{g} / \mathrm{mL}$, giving an $\mathrm{IC}_{50}=16.2 \mu \mathrm{g} / \mathrm{mL}$. A maximum $\mathrm{DPPH}^{\bullet}$ inhibition of 69.2 and $70.4 \%$, respectively, were obtained for the 


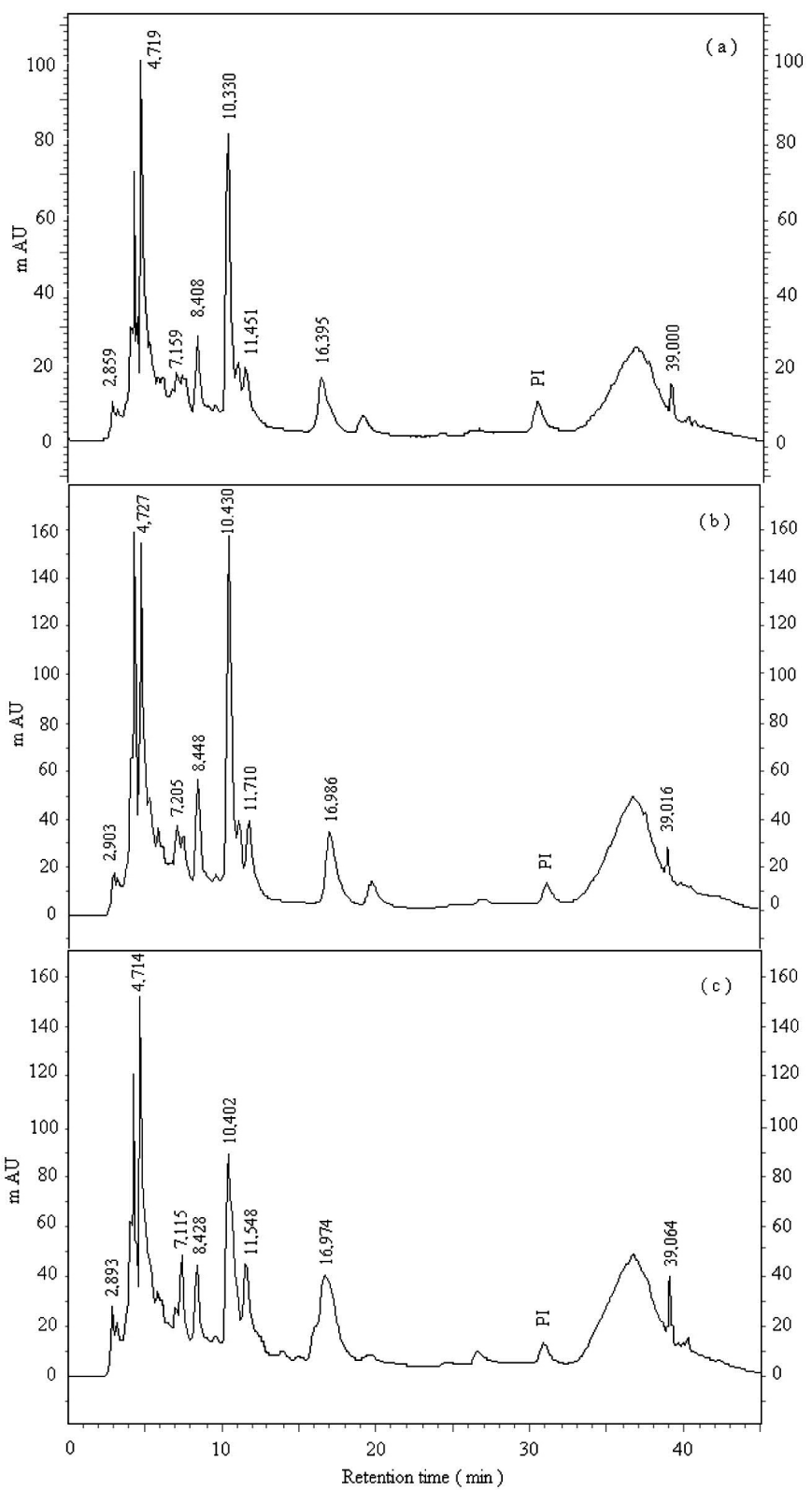

FIGURE 1 - HPLC fingerprint analysis of the Bauhinia forficata extracts (a: concentrated extract, b: spouted bed dried extract, and c: spray dried extract).

spouted bed and for the spray dried extracts. These results were reached at concentrations of $55.5 \mu \mathrm{g} / \mathrm{mL}$ of the extract material, giving $\mathrm{IC}_{50}$ values of 12.2 and $12.9 \mu \mathrm{g} / \mathrm{mL}$, respectively. The slight decreases in the maximum scavenging activity of the dried extracts may be associated with the occurrence of oxidative reactions, decomposition of thermo labile compounds or even losses of volatile substances induced by the heat. A review of the influence of the processing on the antioxidant properties of foods was presented by Nicoli, Anese and Parpinel (1999). According to these authors, the changes occurred during the processing are expected to affect the content, activity and bioavailability of the bioactive compounds. In addition, compounds capable of providing a synergistic effect for antioxidant activity could be damaged or removed due the drying, contributing for the reduction of the antioxidant effectiveness of the dried product (Cousins et al., 2007; Djeridane et al., 2006; Ungar, Osundahunsi, Shimoni, 2003).

The effects of the $B$. forficata extracts on inhibition of lipid peroxidation induced by $\mathrm{Fe}^{+2} /$ citrate were investigated by the production of MDA-TBA complex (absorbance reading at $535 \mathrm{~nm}$ ). Quercetin inhibited the lipid peroxidation following a concentration-dependent manner, as shown in Casagrande et al., (2006). Significant inhibitory activity of the lipid peroxidation as compared to the positive control ( $100 \%$ complex MDA-TBA) was demonstrated by quercetin, which presented an $\mathrm{IC}_{50}=0.34 \mu \mathrm{g} / \mathrm{mL}$. The maximum percentage of formed MDA inhibition was obtained using $1 \mu \mathrm{g} / \mathrm{mL}$ for quercetin. At a higher concentration $(2.5 \mu \mathrm{g} / \mathrm{mL})$, a plateau effect was observed. Table $\mathrm{V}$ show the experimental results of the lipid peroxidation inhibition obtained for the concentrated, spouted bed and spray dried extracts. It can be seen that the anti-lipid peroxidation activity of the extracts of $B$. forficata is concentration dependent. The maximum inhibition falls from 80.3 to $64.0 \%$. The $\mathrm{IC}_{50}$ values obtained for the concentrated, spouted bed and spray dried extracts were, respectively, $22.5,25.9$, and $19.4 \mu \mathrm{g} / \mathrm{mL}$ in the reaction medium. Thus, the $B$. forficata extracts were able to inhibit the lipid peroxidation induced by the $\mathrm{Fe}^{+2} /$ citrate, evidencing their strong antioxidant properties.

Sousa et al., (2004), investigated the in vitro antioxidant potential of kaempferitrin (a isolate compound found in the Bauhinia forficata leaves) by the scavenging of free radicals (DPPH), inhibition of the prooxidant enzyme myeloperoxidase (MPO), and prevention of the lipid peroxidation. The results showed high reactivity with 1,1-diphenyl-2-picrylhydrazyl, $\mathrm{IC}_{50}$ of $84.0 \pm 7.8 \mu \mathrm{M}$, inhibition of the myeloperoxidase activity $\left(\mathrm{K}_{0.5}=86.0 \pm 9.9 \mu \mathrm{M}\right)$, and a decrease in the lipid peroxidation induced by ascorbyl radical either in microsomes or in asolectin and phosphatidylcholine liposomes with $\mathrm{IC}_{50}$ of $320.0 \pm 14.1 \mu \mathrm{M}$, $22.3 \pm 8.3 \mu \mathrm{M}$ and $112.0 \pm 8.8 \mu \mathrm{M}$, respectively. The authors used quercetin as a positive control, obtaining (as expected), a strong antioxidant activity against lipid peroxidation with an $\mathrm{IC}_{50}$ in liver microsomes of 125.0 $\pm 5.0 \mu \mathrm{M}$ and, essentially, the same value of $80 \pm 6.0 \mu \mathrm{M}$ in asolectin and phosphatidylcholine liposomes. These results indicate that kaempferitrin is 2-3 times less potent than quercetin.

Hot air drying (spray and spouted bed dryers) implies thermal treatment, and losses of polyphenols compounds 
TABLE IV - Antiradical activity of Bauhinia forficata extracts observed with DPPH

\begin{tabular}{lccc}
\hline & Concentration $(\mu \mathrm{g} / \mathrm{mL})$ & DPPH Inhibition* $(\%)$ & $\mathrm{IC}_{50}(\mu \mathrm{g} / \mathrm{mL})$ \\
\hline & 1.96 & $9.48 \pm 0.74$ & \\
EC extract & 3.92 & $14.53 \pm 0.45$ & \\
& 7.84 & $16.76 \pm 0.65$ & \\
& 19.2 & $44.08 \pm 0.81$ & 12.2 \\
& 39.2 & $76.13 \pm 0.22$ & \\
SB dried extract & 3.47 & $21.18 \pm 0.38$ & \\
& 6.94 & $36.26 \pm 0.74$ & 12.9 \\
& 13.9 & $56.90 \pm 0.74$ & \\
\hline & 27.8 & $68.80 \pm 0.46$ & \\
SD dried extract & 55.5 & $69.17 \pm 0.76$ & \\
& 3.47 & $37.34 \pm 0.76$ & \\
& 6.94 & $30.77 \pm 0.48$ & \\
& 13.9 & $53.05 \pm 0.38$ & \\
& 27.8 & $70.13 \pm 0.46 \pm 0.26$ & \\
\hline
\end{tabular}

$* \mathrm{n}=5 ;$ mean $\pm \mathrm{sd}$

TABLE V - Antiradical activity of Bauhinia forficata extracts observed with lipidic peroxidation assays (LPO)

\begin{tabular}{lccc}
\hline & Concentration $(\mu \mathrm{g} / \mathrm{mL})$ & Inhibition $\mathrm{LPO}^{*}(\%)$ & $\mathrm{IC}_{50}(\mu \mathrm{g} / \mathrm{mL})$ \\
\hline & 1.96 & $9.48 \pm 0.74$ & \\
EC extract & 3.92 & $14.53 \pm 0.45$ & 22.5 \\
& 7.84 & $16.76 \pm 0.65$ & \\
& 19.2 & $44.08 \pm 0.81$ & 25.9 \\
& 39.2 & $76.13 \pm 0.22$ & \\
SB dried extract & 3.47 & $6.13 \pm 0.75$ & \\
& 6.94 & $19.28 \pm 0.64$ & \\
& 13.9 & $34.65 \pm 0.55$ & 30.3 \\
\hline
\end{tabular}

$* \mathrm{n}=5 ;$ mean $\pm \mathrm{sd}$

may be expected. The degradation of the polyphenols depends on the herbal matrix and processing conditions (Sensoy et al., 2006). Figure 2.a presents a comparison between the concentration of the total flavonoids and the antioxidant activity of the $B$. forficata extracts. As can be seen, the total antioxidant activity evaluated by $\mathrm{DPPH}^{\bullet}$ and 

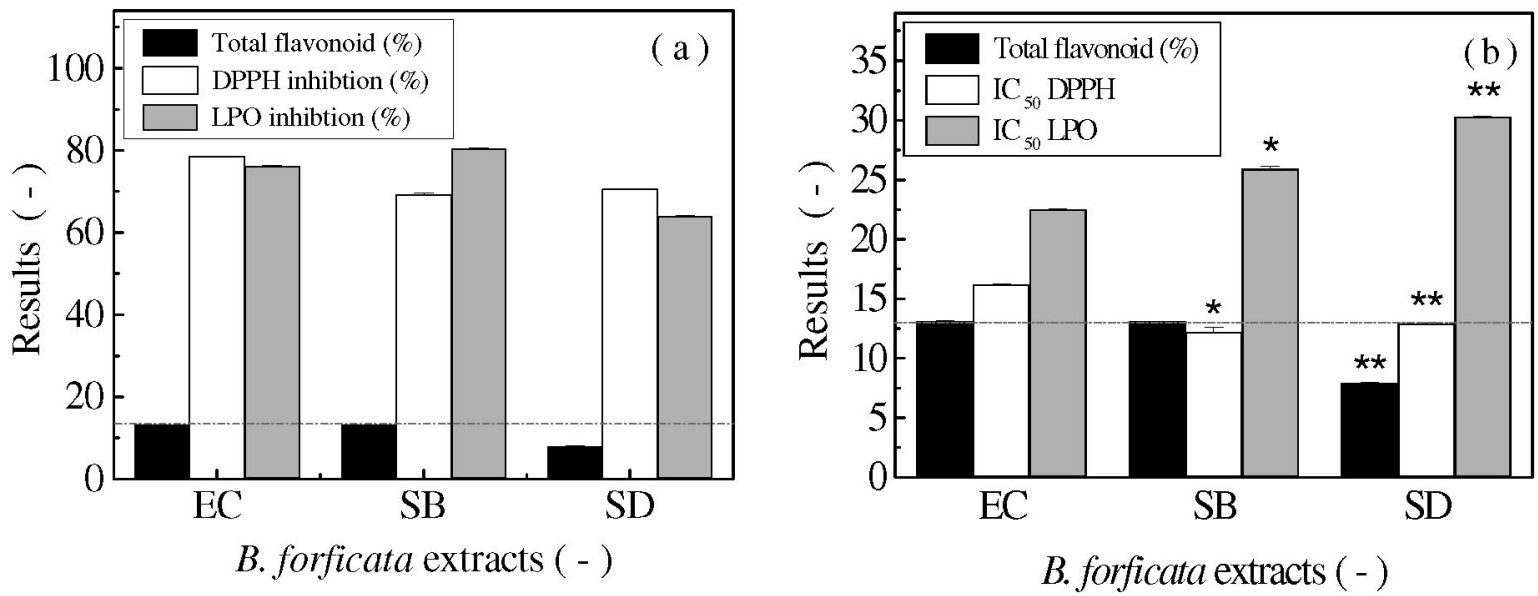

FIGURE 2 - Comparison between total flavonoid contents, maximum anti-radical activity (Fig. a), and $\mathrm{IC}_{50}$ (Fig. b), for the Bauhinia forficata extracts. Statistical analysis was performed by one-way ANOVA followed by Bonferroni's test of multiple comparisons test. "Significant statistical difference compared to EC $(P<0.05) .{ }^{*}$ Significant statistical difference compared to EC and $\mathrm{SB}(P<0.05)$.

inhibition of lipid peroxidation methods do not present a direct relationship with the total flavonoids concentration. Interestingly, although the spray dried extract presented lower concentration of total flavonoids than the spouted bed one, they presented similar antioxidant activity in both experimental models. The relation between the total flavonoid content and the $\mathrm{IC}_{50}$ values is presented in Figure 2.b.

According to Mrkì et al. (2006), oxidation reactions may take place during drying and polyphenols with an intermediate oxidation state can exhibit higher radical scavenging activity than non-oxidized polyphenols. High temperature drying could further cause the formation of Maillard reaction products (MRPs). These compounds have been shown to act as antioxidants in dried foodstuffs, individually or in synergism with the naturally occurring antioxidants. Maillard reactions, which occurs when sugars condense with free amino acids, peptides or proteins, leads to the formation of a wide variety of brown melanoidins. Thus, the loss of natural antioxidants in heated foods could be minimized or compensated by the formation of non-nutrient antioxidants such as MRPs, enhancing the overall antioxidant properties of the product (Nicoli et al., 1997). These factors may be the responsible agents for the behavior shown in Figure 2.b.

The spouted bed and spray dried extracts present distinct color characteristics, as can be seen in Figure 3. Changes in coloration (yellow-green for spouted bed extracts and yellow-brown for spray dried extract), may indicate the development and the extent of browning that contributes to the formation of compounds with prooxidant properties, justifying the antioxidant properties presented by the spray dried extracts, even with the high flavonoids degradation rate (39.9\%) obtained.



FIGURE 3 - Colour characteristics of the dried extracts (a: spouted bed dried extract, b: spray dried extract).

\section{ACKNOWLEDGEMENT}

The authors thank to The State of São Paulo Research Foundation (FAPESP) for the fellowship to the first author and for the whole project financial support (Proc. 03/08317-1 and 01/10140-7).

\section{REFERENCES}

BLOIS, M.S. Antioxidant determinations by the use of a stable free radical. Nature, v.26, p.1199-1200, 1958.

BRAND-WILLIAMS, W.; CUVELIER, M.E.; BERSET, C. Use of a free radical method to evaluate antioxidant activity. Lebensm. Wiss. u.-Technol., v.25, p. 25-30, 1995.

BRIGHENTE, I.M.C.; DIAS, M.; VERDI, L.G.; PIZZOLATTI, M.G. Activity and total phenolic content of some Brazilian species. Pharm. Biol., v.45, n.2, p.156-161, 2007. 
CAIN, K.; SKILLETER, D.N. Preparation of and use of mitochondria in toxicological research, In: Snell K, Mullock B (Eds.). Biochemical Toxicology - A Practical Approach., Oxford: IRL Press, 1987. p. 217-254.

CASAGRANDE, R.; GEORGETTI, S.R.; VERRI Jr, W.; BORIN, M.F.; LOPEZ, R.F.V.; FONSECA, M.J.V. In vitro evaluation of quercetin cutaneous absorption from topical formulations and its functional stability by antioxidant activity. Int. J. Pharm. , v.328, p. 183-190, 2007.

COUSINS, M.; ADELBERG, J.; CHEN, F.; RIECK, J. Antioxidant capacity of fresh and dried rhizomes from four clones of turmeric (Curcuma longa L.) grown in vitro. Ind. Crops Prod., v.25, n.2, p.129-135, 2007.

DAMASCENO, D.C.; VOLPATO, G.T.; CALDERON, I.M.P.; AGUILAR, R.; RUDGE, M.V.C. Effect of Bauhinia forficata extract in diabetic pregnant rats: maternal repercussions. Phytomedicine, v.11, p.196-201, 2004.

DJERIDANE, A.; YOUSFI, M.; NADJEMI, B.; BOUTASSOUNA, D.; STOCKER, P.; VIDAL, N. Antioxidant activity of some algerian medicinal plants extracts containing phenolic compounds. Food Chem., v.97, p.654-660, 2006.

FEJES, S.A.; BLÁZOVICS, A.; LUGASI, E.; LEMBERKOVICS, G.; PETRI, A.K. In vitro antioxidant activity of Anthriscus cerefolium L. (Hoffm.) extracts. $J$. Ethnopharmacol., v.69, p.259-265, 2000.

FREITAG, G. Guidelines on dissolution profiles comparison. Drug Inf. J., v.35, p.865-874, 2001.

GEORGETTI, S.R.; CASAGRANDE, R.; VICENTINI, F.T.M.D.; VERRI, W.A.; FONSECA, M.J.V. Evaluation of the antioxidant activity of soybean extract by different in vitro methods and investigation of this activity after its incorporation in topical formulations. Eur. J. Pharm. Biopharm., v.64, n.1, p.99-106, 2006.

GIOVANELLI, G.; PARADISO, A. Stability of dried and intermediate moisture tomato pulp during storage. J. Agric. Food Chem., v.50, p.7277-7281, 2002.

JORGE, A.P.; HORST, H.; SOUSA, E.; PIZZOLATTI, M.G.; SILVA, F.R.M.B. Insulinomometic effects of kaempferitrin on glycaemia and ${ }^{14} \mathrm{C}$-glucose uptake in rat soleus muscle. Chemico-Biol. Interactions, v.149, p.89-96, 2004.
KULEVANOVA, S.; STEFOVA, M.; STAFILOV, T. Determination of total flavonoids and quercetin in Hyperici herba and its aqueous, aqueous-ethanolic and oil extracts. Acta Pharm., v.50, p.29-37, 2000.

MENEZES, F.S.; MINTO, A.B.M.; RUELA, H.S.; KUSTER, R.M.; SHERIDAN, H.; FRANKISH, N. Hypoglycemic activity of two Brazilian Bauhinia species: Bauhinia forficata L. and Bauhinia monandra Kurz. Braz. J. Pharmacogn., v.17 n.1, p. 08-13, 2007.

MOEIN, S.; FARZAMI, B.; KHAGHANI, S.; MOEIN, M.R.; LARIJANI, B.A. Antioxidant properties and protective effect on cell cytotoxicity of Salvia mirzayani. Pharm. Biol., v.45, n.2, p.458-463, 2007.

MRKÌC, V.; COCCI, E.; DALLA ROSA, M.; SACCHETTI, G. Effect of drying conditions on bioactive compounds and antioxidant activity of broccoli (Brassica oleracea L.). J. Sci. Food Agric., v.86, p.1559-1566, 2006.

NICOLI, M.C.; ANESE, M.; PARPINEL, M.T.; FRANCESCHI, S.; LERICI, C.R. Loss and/or formation of antioxidants during food processing and storage. Cancer Lett., v.114, p.71-74, 1997.

NICOLI, M.C.; ANESE, M.; PARPINEL, M. Influence of processing on the antioxidant properties of fruit and vegetables. Trends Food Sci. Technol., v.10, p.94-100, 1999.

NUUTILA, A.M.; KAMMIOVIRTA, K.; OKSMANCALDENTEY, M. Comparison of methods for the hydrolysis of flavonoids and phenolic acids from onion and spinach for HPLC analysis. Food. Chem., v.76, p.519$525,2002$.

OLIVEIRA, C.Z.; MAIORANO, V.A.; MARCUSSI, S.; SANT'ANA, C.D.; JANUÁRIO, A.H.; LOURENÇO, M.V.; SAMPAIO, S.V.; FRANÇA, S.C.; PEREIRA, P.S.; SOARES, A.M. Anticoagulant and antifibrinogenolytic properties of the aqueous extract from Bauhinia forficata against snake venoms. J. Ethnopharmacol., v.98, p.213$216,2005$.

OLIVEIRA, W.P.; BOTT, R.F.; SOUZA, C.R.F. Manufacture of standardized dried extracts from medicinal Brazilian plants. Drying Technol., v.24, n.4, p.523-533, 2006. 
PEPATO, M.T.; BAVIERA, A.M.; VENDRAMINI, R.C.; BRUNETTI, I.L. Evaluation of toxicity after one-months treatment with Bauhinia forficata decoction in streptozotocininduced diabetic rats. BMC Complement. Altern. Med. (abreviar conforme ISSN), v.4, n.7, p.1-7, 2004.

PEPATO, M.T.; KELLER, E.H.; BAVIERA, A.M.; KETTELHUT, I.C.; VENDRAMINI, R.C.; BRUNETTI, I.L. Anti-diabetic activity of Bauhinia forficata decoction in streptozotocindiabetic rats. J. Ethnopharmacol., v.81, p.191-197, 2002.

PIETTA, P.; MAURI, P. Analysis of flavonoids in medicinal plants. Methods Enzimol., v.335, p.26-45, 2001.

PINHEIRO, T.S.D.B.; JOHANASSON, L.A.P.; PIZZOLATTI, M.G.; BIAVATTI, M.W. Comparative assessment of kaempferitrin from medicinal extracts of Bauhinia forficata Link. J. Pharm. Biomed. Anal., v.41, p. 431-436, 2006.

RODRIGUES, T.; SANTOS,A.C.; PIGOSO,A.A.; MINGATTO, F.E.; UYEMURA, S.A.; CURTI, C. Thioridazine interacts with the membrane of mitochondria acquiring antioxidant activity toward apoptosis - potentially implicated mechanisms British. J. Pharmacol., v.36, p.136-142, 2002.

RUNHA, F.P.; CORDEIRO, D.S.; PEREIRA, C.A.M.; VILEGAS, J.; OLIVEIRA, W.P. Production of dry extracts of medicinal Brazilian plants by spouted bed process: development of the process and evaluation of thermal degradation during drying operation. Food Bioprod. Process., v.79, n.C3, p.160-168, 2001.

SABU, M.C.; KUTTAN, R. Anti-diabetic activity of medicinal plants and its relationship with their antioxidant property. J. Ethnopharmacol., v.81, p.155-160, 2002.

SANTOS, A.C.; UYEMURA, S.A.; LOPES, J.L.C.; BAZON, J.N.; MINGATTO, F.E.; CURTI, C. Effect of naturally occurring flavonoids on lipid peroxidation and membrane permeability transition in mitochondria. Free Radic. Biol. Med., v.24, p. 1455-1461, 1998.

SARTORELLI, D.S.; FRANCO, L.J. Trends in diabetes mellitus in Brazil: the role of the nutritional transition. Cad. Saúde Púb., v.19, n.1, p.S29-S36, 2003.

SENSOY, I.; ROSEN, R.T.; HO, C.T,; KARWE, M.V. Effect of processing on buckwheat phenolics and antioxidant activity. Food Chem., v.99, p.388-393, 2006.
SILVA, K.L.; BIAVATTI, M.W.; LEITE, S.N.; YUNES, R.A.; MONACHE, F.; CECHINEL-FILHO, V. Phytochemical and pharmacognostic investigation of Bauhinia forficata Link. Z. Naturforsch. C., v.55, p.478-480, 2000.

SILVA, K.L.; CECHINEL-FILHO, V. Plantas do gênero Bauhinia: composição química e potencial farmacológico. Quim. Nova, v.25, n.3, p.449-454, 2002.

SOUSA, E.; ZANATTA, L.; SEIFRIZ, I.; CRECZYNSKIPASA, T.B.; PIZZOLATTI, M.G.; SZPOGANICZ, B.; SILVA, F.R.M.B. Hypoglycemic effect and antioxidant potential of kaempferol-3,7-O- $(\alpha)$-dirhamnoside from Bauhinia forficata leaves. J. Natural Product, v.67, p.829832, 2004.

SOUZA, C.R.F. Comparative study of the production of dried extract of Bauhinia forficata Link by spray and spouted bed drying. Master Thesis, PPG-FCFRP/USP, Ribeirão Preto, SP, Brazil, p.180, 2003.

SOUZA, C.R.F.; OLIVEIRA, W.P. Powder properties and system behavior during spray drying of Bauhinia forficata Link extract. Drying Technol., v.24, n.6, p.735-749, 2006.

SOUZA, C.R.F.; OLIVEIRA, W.P. Spouted bed drying of Bauhinia forficata Link extract: effect of the position of the feed atomizer and operating conditions on equipment performance and product properties. Braz. J. Chem. Eng., v.22, n.2, p.239-247, 2005 .

TZENG, G.S.; CHEN, H.J.; WANG, Y.Y.; WAN, C.C. The effects of roughening on teflon surfaces. Surface Coatings Technol., v.89, p.108-113, 1997.

UNGAR, Y.; OSUNDAHUNSI, O.F.; SHIMONI, E. Thermal stability of genistein and daidzein its effect on their antioxidant activity. J. Agric. Food Chem., v.51, p.43944399, 2003

VOLPATO, G.T.; DAMASCENO, D.C.; RUDGE, M.V.C.; PADOVANI, C.R.; CALDERON, I.M.P. Effect of Bauhinia forficata aqueous extract on the maternal-fetal outcome and oxidative stress biomarkers of streptozotocin-induced diabetic rats. J. Ethnopharm., v.116, p. 131-137, 2008.

Received for publication on $18^{\text {th }}$ february 2008 Accepted for publication on $16^{\text {th }}$ november 2008 